\title{
Spatial Distribution of Diarrhoea and Microbial Quality of Domestic Water during an Outbreak of Diarrhoea in the Tshikuwi Community in Venda, South Africa
}

\author{
Pascal O. Bessong', John O. Odiyo², Justice N. Musekene ${ }^{3}$, and Abera Tessema ${ }^{4}$ \\ 'Laboratory for Molecular Microbiology, Department of Microbiology, ${ }^{2}$ Department of Hydrology and Water Resources, and \\ ${ }^{3}$ Department of Mining and Environmental Geology, University of Venda, South Africa, and ${ }^{4}$ Department of Water Affairs and \\ Forestry, Pretoria, South Africa
}

\begin{abstract}
Total microbial quality assessment and geographical information system were used for evaluating the quality of water and the spatial distribution of diarrhoea cases in Tshikuwi, a rural community in South Africa, during an outbreak of diarrhoea. The water-abstraction points included two groundwater storage tanks, namely Tank 1 and Tank 2 and the Khandanama river. Indicator microbial counts for total coliforms, faecal coliforms, enterococci, and heterotrophic bacteria exceeded the limit for no risk as stipulated by the South African water-quality guidelines for domestic use for Tank 1 and the Khandanama river. Vibrio, Salmonella, and Shigella species were prevalent in the Khandanama river. The spatial distribution of diarrhoea cases showed a hot-spot of diarrhoea cases close to Tank 1 and the Khandanama river. Results of chi-square analysis showed that the proportion of infection from each water source was different or that infection depends on the type of water source $(\alpha=0.05)$. The demonstrated spatial clustering of diarrhoea cases might have been influenced by the poor microbial quality of water used from Tank 1 and the Khandanama river. The results further highlight the urgent need of water-treatment facilities and monitoring of water quality in rural communities of South Africa.
\end{abstract}

Key words: Diarrhoea; Disease outbreaks; Spatial distribution; Water pollution; Water supply; South Africa

\section{INTRODUCTION}

Worldwide, around 1.1 billion people have no access to clean water sources, and 2.4 billion have no basic sanitation. Each year, there are approximately four billion cases of diarrhoea worldwide, and infectious diarrhoea is widespread throughout the developing world (1). Poor quality of water, sanitation, and hygiene account for some 1.7 million deaths a year, mainly due to infectious diarrhoea. Nine of 10 of such deaths occur in children, with a significant majority of deaths in developing countries (2).

Correspondence and reprint requests should be addressed to:

Dr. Pascal O. Bessong

Laboratory for Molecular Microbiology

Department of Microbiology

University of Venda

PMB X5050

Thohoyandou 0950

South Africa

Email: bessong@univen.ac.za

Fax: +27 159624749
In many rural areas of South Africa, such as the Venda region, clean potable water and sanitation are either lacking or inadequate (3). Village communities depend on untreated water from wells, rivers, and other surface-water for drinking, laundry and recreational purposes. A previous report on the microbial quality of river-water used by the Venda rural communities of South Africa showed that water from the sources was unsafe for human consumption (4). Escherichia coli, Shigella, and Salmonella were the predominant potential pathogens isolated. In addition, microbial counts for faecal coliforms, total coliforms, heterotrophic counts, and enterococci exceeded the acceptable limits prescribed by the South Africa Department of Water Affairs and Forestry guidelines (5). The link between poor microbial water quality and infectious diarrhoea is well-established (6-9), and geographic information system (GIS) has been shown to be vital in mapping the spread of infectious diseases, including diarrhoea, and aiding in control strategies (10-13). However, despite numerous outbreaks of diarrhoea in several rural commu- 
nities in Venda, South Africa, the application of GIS technology to assist in the identification of occurrence of diarrhoea aiming at assisting its control has not been reported.

During June-July 2006, there was an outbreak of diarrhoea in Tshikuwi, a village in the Venda area of the Limpopo province of South Africa. Information gathered from the local clinic indicated that 37 cases of diarrhoea in children aged less than five years and 23 cases of diarrhoea in individuals aged more than five years were recorded in June 2006. One question that had to be answered was whether there was any epidemiological link between the water used by the residents of the community and the outbreak of diarrhoea and which parts of the community were affected most. This study set out to determine the microbial quality of water from the three water-abstraction points in the Tshikuwi community during an outbreak of diarrhoea and to identify whether there was a link between the water used by the residents and the diarrhoea cases.

\section{MATERIALS AND METHODS}

\section{Study area and population}

Tshikuwi is located in Makhado municipality in Vhembe district, Limpopo province, South Africa. The geographic grid of the study area is located between $22^{\circ} 55^{\prime} \mathrm{S}$ and $22^{\circ} 57^{\prime} \mathrm{S}$ latitude and $29^{\circ} 54^{\prime} \mathrm{E}$ and $29^{\circ} 59^{\prime} \mathrm{E}$ longitude. The population size is approximately 5,300, with a high unemployment rate and limited clean potable water infrastructure.

\section{Household identification of diarrhoea and spatial mapping}

Stratified random sampling was applied to $40 \%$ of the Tshikuwi community households ( $\mathrm{n}=866)$ during the outbreak of diarrhoea. The survey questionnaire was administered on 354 of 866 households to identify cases or no cases of diarrhoea. Acute diarrhoea, investigated in this study, was defined as the passing of three or more loose or watery stools per day. No attempt was made to identify potential diarrhoegenic organisms from stools of diarrhoea patients. Other data captured with the survey questionnaire in all the 354 sampled households included source of water, treatment of water before use, sanitation, and hygiene, for example the type of toilet used. Interviews and collection of household demographic data were conducted after a signed informed consent had been obtained from the head of each household. A global positioning device was used for recording the geographical co- ordinates of diarrhoea-affected households and the points of water sources. To visualize the spatial distribution of households and the sources of water used by the community, the ArcGIS software (version 9.1) was used. The ArcGIS software uses proportional symbol to represent the total number of people affected in each household. The size of the plotted symbol (circle) proportionately quantifies the number of affected people in each household. In the present study, a circle was scaled and used for displaying the total number of people affected at each household. The plotted circle was proportional to the number of people affected by the outbreak of diarrhoea. GIS technology is mostly useful in wide-area application with various sources of water and population exposures. However, the technology can also be used where there are limited data points to provide clarity and simplify information for dissemination, for example, in diarrhoea cases linked to water sources.

\section{Evaluation of total microbial water quality}

The available water-abstraction points in Tshikuwi comprised Tank 1, Tank 2, and the Khandanama river. Tank 1 and 2 are recharged by two different boreholes. The boreholes are located about 50 metres from the bank of the Khandanama river. The borehole recharging Tank 1 is upstream and about 500 metres from the borehole recharging Tank 2 . Water from the boreholes is pumped through polyvinyl pipes to the tanks without prior treatment. The tanks were supported by pedestals.

Two hundred $\mathrm{mL}$ of water was sampled aseptically into bottle containers and transported on ice for processing within six hours. Samples were analyzed for total coliforms, faecal coliforms, enterococci, and heterotrophs by the membrane filtration method. One hundred $\mathrm{mL}$ of water sample was filtered through a $0.45-\mu \mathrm{m}$ pore-size membrane. MEndoAgar, mFC agar, and m-enterococcus agar were used for the cultivation of total coliforms, faecal coliforms, and enterococci respectively. Agar plates were prepared according to the instructions of the manufacturers. Plates were incubated at $37^{\circ} \mathrm{C}$ for 24 hours, $37^{\circ} \mathrm{C}$ for 48 hours, and $44.5^{\circ} \mathrm{C}$ for 24 hours for total coliforms, faecal coliforms, and enterococci respectively. Heterotrophs were determined by the pour-plate technique using plate count agar (PCA). Ten-fold serial dilutions were made for each sample. One $\mathrm{mL}$ each from the $10^{-1}, 10^{-2}, 10^{-3}$, and $10^{-4}$ dilutions was spread on PCA, followed by incubation at $37^{\circ} \mathrm{C}$ for 48 hours. Water samples were tested in duplicate. The water-points were sampled 
and analyzed twice during the outbreak in July 2006 with a three-week interval between the samplings. A third sampling was conducted in October 2006 at the end of the outbreak.

\section{Isolation and identification of diarrhoegenic bacteria}

It was considered relevant to isolate and identify bacteria which have been incriminated in outbreaks of diarrhoea in other regions of South Africa. For this purpose, the water-points were screened for Salmonella, Shigella, and Vibrio. Isolation was performed by spreading $0.1 \mathrm{~mL}$ of water samples on Salmonella-Shigella agar, deoxycholate citrate agar for the presumptive isolation of Salmonella and Shigella, and thiocitrate bile salt agar for the isolation of Vibrio. Suspected colonies were confirmed with the API 20E test-kit (bioMerieux) according to the instructions of the manufacturer.

\section{RESULTS}

\section{Sanitation and hygiene}

All the $40 \%$ of the households investigated completed the questionnaire. Each household had a pit-latrine which was in use, and none had a flush toilet. Water collected from the abstraction-points for domestic use, such as drinking, cooking, and laundry, was not treated in any way before use in any households. Generally, water collected was stored in jerry-cans or buckets for several days before refilling.

\section{Prevalence of diarrhoea and spatial distribution}

At the time of the survey, administration of the questionnaire established that there were 866 households in the study area. Each household comprised an average of six persons. By approximation, the population of the area was 5,196 . Of the $40 \%$ $(n=354)$ of the households investigated, 9\% $(n=32)$ had one or more cases of diarrhoea. Twenty-six of the 32 households affected used groundwater from Tank 1 and Tank 2 while only six used water from the river. However, of 69 individuals who used Tank 1, 29 (42\%) had diarrhoea; 16 (34\%) of 47 individuals who used Tank 2 had diarrhoea; and 15 (52\%) of the 29 individuals who used the Khandanama river had diarrhoea. Sixty (41\%) of 145 individuals in the households studied had diarrhoea. Using the chi-square test, it was determined that the proportion of infection from each source of water was different or that infection depends on the type of water source $(\alpha=0.05)$.

Spatial distribution using GIS mapping of diarrhoea cases placed the hot-spot of the outbreak upstream but towards the middle of the study community, although a significant number of cases were indicated to the south of the study area closer to Tank 2 (Fig. 1). Overall, it could be observed that, although a hot-spot was identified upstream but towards the middle of the study area, the outbreak of diarrhoea was, to an extent, distributed throughout the community (Fig. 1). This is supported by the fact that when the percentages of affected individuals who used the different sources of water were compared, there was no significant difference between them. This is because of the fact that Tank 1 and Tank 2 were supplied by two different boreholes in the vicinity of the Khandanama river through pipes, and the water was not treated prior to distribution. By implication, if the Khandanama river was contaminated with diarrhoea-causing pathogens and there is surface-groundwater interaction, Tank 1 and Tank 2 would be supplied with contaminated water. Depending on the flow network, the groundwater level and the ability of the soil to permit movement of microbes, Tank 1 and Tank 2 and even the Khandanama river could be contaminated from pit-latrines in the study area. Since the tanks were built to bring the river-water closer to the residents, their usage would be higher, and consequently, more cases of diarrhoea may be associated with the water-tanks.

Stratified random sampling provides for a lower variability within subgroups than the variability for the population as a whole and with the possibility of making meaningful inferences among subgroups.

\section{Total microbial quality and isolation of potential diarrhoea-causing bacteria from water sources}

The total microbial quality taking into account the presence of faecal coliform, total coliform, enterococci, and heterotroph bacteria as indicator organisms, is detailed in the table. The faecal coliform, enterococci, and total coliform counts far exceeded the recommended minimum values of the South African water-quality guidelines of the Department of Water Affairs and Forestry for Tank 1 and the Khandanama river at all the time periods of evaluation. All the sources also had high values of heterotrophic counts which exceeded the limit for no risk, except Tank 2 which, at two different time periods of assessment (29 July and 2 October 2006), had its heterotrophic count within the acceptable limit. Tank 2 was relatively less contaminated as no faecal coliform, total coliforms, and enterococci 


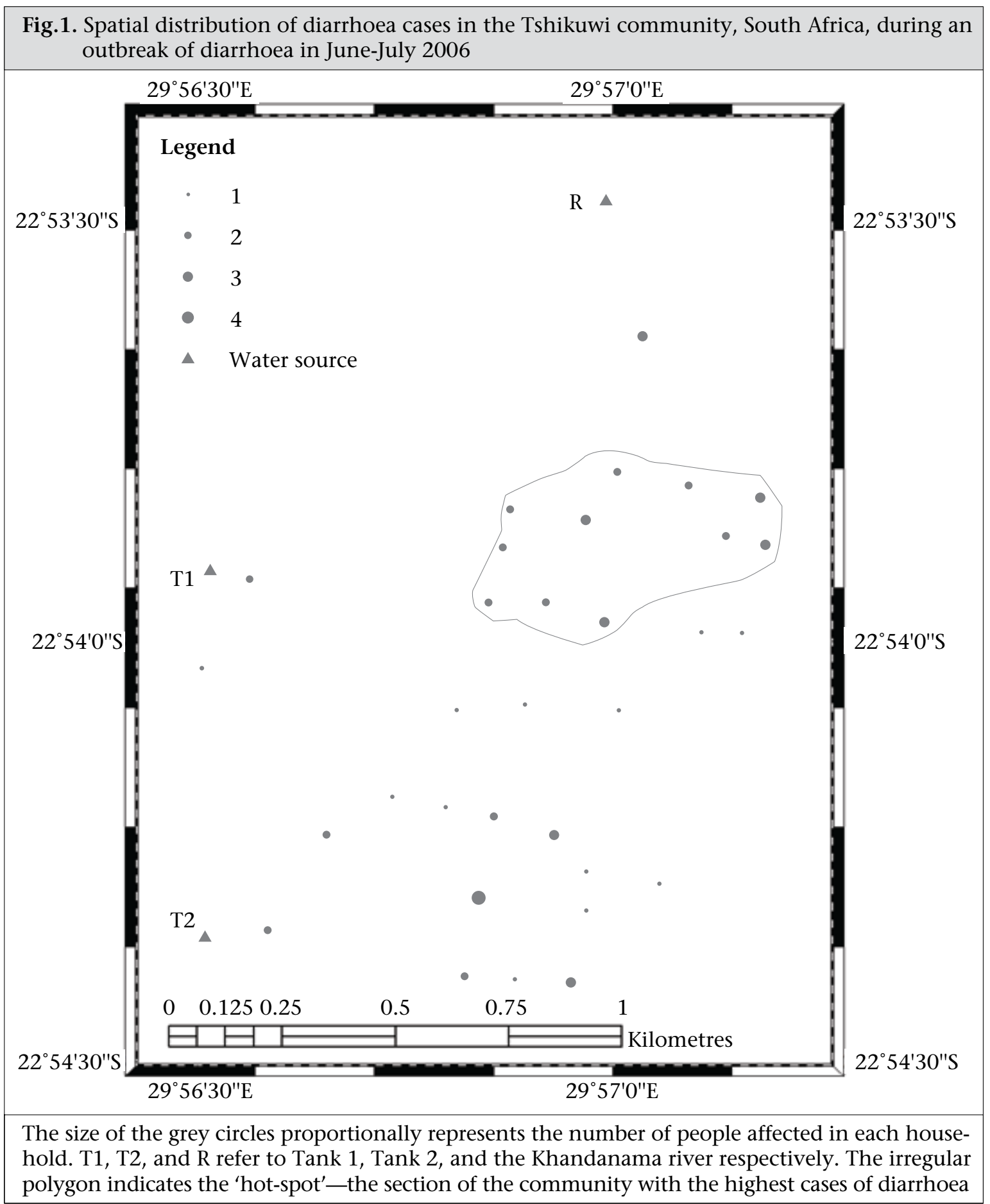

were detected during any time periods at which water was evaluated. The near-absence of indicator organisms in Tank 2 is surprising since both Tank 1 and Tank 2 are fed by boreholes close to the bank of the Khandanama river. The borehole recharging Tank 1 is upstream of that recharging Tank 2; so, the source of the microbial contaminants was probably upstream of both the boreholes for their presence to be detected in Tank 1. Local geological barriers within the aquifer and/or filtration through attachment to soil media reduce the number of microbes from the source further downstream. This could have potentially contributed to the lack of detection of microbial contaminants in Tank 2. Nevertheless, the implication of the high indicator values in Tank 1 and the Khandanama river is that the sources of water had signs of faecal contamination and the possible presence of diarrhoegenic organisms. 


\begin{tabular}{|c|c|c|c|c|c|}
\hline \multicolumn{6}{|c|}{$\begin{array}{l}\text { Table. Microbial quality of domestic water collected from three sources used by residents of the Tshikuwi } \\
\text { community, South Africa, during an outbreak of diarrhoea }\end{array}$} \\
\hline Water source & $\begin{array}{l}\text { Date of water } \\
\text { sampling }\end{array}$ & $\begin{array}{c}\text { Faecal coliform } \\
\text { (cfu/100 mL) } \\
{ }^{\star} \text { Limit for no } \\
\text { risk= } \\
0 \mathrm{cfu} / 100 \mathrm{~mL}\end{array}$ & $\begin{array}{c}\text { Total coliform } \\
\text { (cfu/100 mL) } \\
\text { Limit for no } \\
\text { risk= } \\
0-5 \mathrm{cfu} / 100 \mathrm{~mL}\end{array}$ & $\begin{array}{c}\text { Enterococci } \\
(\mathrm{cfu} / 100 \mathrm{~mL}) \\
\text { Limit for } \\
\text { no risk }=0-5 \\
\mathrm{cfu} / 100 \mathrm{~mL}\end{array}$ & $\begin{array}{c}\text { Heterotroph } \\
(\mathrm{cfu} / 1 \mathrm{~mL}) \\
\text { Limit for no } \\
\text { risk }= \\
0-100 \mathrm{cfu} / \mathrm{mL} \\
\end{array}$ \\
\hline \multirow[t]{3}{*}{ Tank 1} & 6 July 2006 & $50.5 \pm 5.0$ & $334.0 \pm 8.5$ & $25.0 \pm 5.0$ & $1.02 \times 103$ \\
\hline & 29 July 2006 & $5.5 \pm 2.1$ & $30.0 \pm 5.7$ & $8.5 \pm 2.0$ & $3.8 \times 102$ \\
\hline & 2 October 2006 & $13.0 \pm 1.4$ & $36.5 \pm 6$ & $6.0 \pm 5.0$ & $4.2 \times 103$ \\
\hline \multirow[t]{3}{*}{ Tank 2} & 6 July 2006 & 0 & 0 & 0 & $7.8 \times 102$ \\
\hline & 29 July 2006 & 0 & 0 & 0 & 5 \\
\hline & 2 October 2006 & 0 & 0 & 0 & 50 \\
\hline \multirow[t]{3}{*}{$\begin{array}{l}\text { Khandanama } \\
\text { river }\end{array}$} & 6 July 2006 & $107.0 \pm 12.7$ & $388.0 \pm 29.7$ & $63.5 \pm 6.4$ & $6.1 \times 103$ \\
\hline & 29 July 2006 & $112.0 \pm 11.3$ & $397.0 \pm 23.3$ & $45.0 \pm 4.2$ & $2.4 \times 104$ \\
\hline & 2 October 2006 & $35.0 \pm 4.2$ & $387.0 \pm 15.6$ & $56.0 \pm 5.7$ & $2.6 \times 104$ \\
\hline \multicolumn{6}{|c|}{$\begin{array}{l}\text { Water samples were analyzed in duplicate. The values for faecal coliforms, total coliforms, and entero- } \\
\text { cocci counts are the means } \pm \text { standard deviations } \\
\text { *The limit for no risk for each of the indicator organisms is as prescribed by the South African water-quali- } \\
\text { ty guidelines for domestic use (5). It could be seen that, during the study period, the faecal coliform, } \\
\text { total coliform, enterococci, and heterotrophic counts were much higher than the recommended mini- } \\
\text { mum for Tank } 1 \text { and the Khandamana river. The counts for Tank } 2 \text { were within the acceptable limits, } \\
\text { except for the heterotrophic counts }\end{array}$} \\
\hline
\end{tabular}

An attempt was made to isolate potential diarrhoegenic bacteria, which have been responsible for the outbreaks of diarrhoea in other regions of South Africa, from the water-extraction points. Vibrio, Salmonella, and Shigella species were identified in the water samples from the Khandanama river only. The Khandanama river is used for bathing, laundry, and swimming. The absence of these organisms in samples taken from Tank 1 and 2 could be as a result of the fact that the organisms occurred in smaller numbers in the tank, and the isolation procedure employed was not optimal to detect small numbers of organisms. Tank 1 and 2 could only have microbial contaminants infiltrated into these from contamination of their groundwater aquifers from either pit-latrines or the Khandanama river. In addition, since aquifer materials (soils) are known to filter out microorganisms, this might have contributed to the non-detection of targeted microorganisms in tank-water. It is also possible that small numbers of organisms may multiply in stored water over time to infectious-dose level. The storage of water in jerry-cans and other containers for several days was observed as a common practice among the households.

\section{DISCUSSION}

This study set out to determine the spatial distribu- tion of diarrhoea and the microbial quality of the water sources during an outbreak of diarrhoea in the Tshikuwi community in Limpopo province of South Africa. Using the stratified random-sampling approach, our study identified a significant clustering of diarrhoea cases to two water-extraction points-Tank 1 and the Khandanama river. This is supported by the chi-square analysis which showed that the proportion of infected persons in the community was associated with the source of water used. Our observation is in contrast to a study in India by Sarkar et al., in which no hot-spot in an outbreak of diarrhoea was found when GIS tools were employed in epidemiologic investigation of acute diarrhoea in a village in southern India (14). However, microbiological examination showed that the water used by the residents of the village had high coliform counts, and the chlorine level was inadequate to decontaminate common pathogens. On the other hand, the outcome of our study is in agreement with a study in Mexico City that linked the rate of diarrhoea in children to the water used for domestic purposes which was also of poor microbial quality (15).

Total microbial quality analyses showed that the water sources-the Khandanama river and two water-storage tanks-were of poor microbial quali- 
ty according to the South African drinking-water quality guidelines (15). In addition, potential diarrahoea-causing organisms, including Vibrio, Salmonella, and Shilgella, were isolated and identified from the Khandanama river.

Isolates of Vibrio, Salmonella, and Shigella from the Khandanama river were not further characterized to species level. However, evidence of their presence was a cause of concern, since these organisms are potentially pathogenic and frequently incriminated in outbreaks of diarrhoea in both developing and developed societies (16-18). Outbreaks of diarrhoea in South Africa have previously been reported in KwaZulu-Natal, and Gauteng and Mpumalanga provinces due to the contamination of rural water sources by Shigella dysenteriae type 1 and Vibrio cholerae $\mathrm{O} 1$ biotype El Tor respectively (19-20). As mentioned in the introduction, previous studies on the quality of water sources used by rural communities in the Venda region of South Africa, the area of the present study, had indicated that most sources of water were contaminated with pathogenic organisms, such as enteropathogenic $E$. coli, Vibrio, Salmonella, Shigella, Aeromonas, and Plesiomonas species (3).

The clinical outcome of the diarrhoea cases in the present study was not investigated; however, it is worthwhile to note that Limpopo province has a relatively high prevalence (19\%) of HIV, and the impact of enteropathogens, such as Shigella, Campylobacter, Shigella, and Plesiomonas shigelloides, in the HIV/AIDS condition has been well-documented (21-25). In South Africa, a significant proportion of HIV/AIDS patients reside in rural areas, which lack good sanitation and adequate supply of potable water (26-27). Many South African rural dwellers use untreated water domestically and are more at risk of the devastating effects of diarrhoea since diarrhoea-causing organisms may be transmitted as a result of poor quality of water, inadequate sanitation, and hygiene (28). Another limitation of the present study was the exclusion of water-borne viruses and parasites, which have been incriminated in diarrhoea. However, recent data have shown that diarrhoegenic parasites, such as Cryptosporidium and Entamoeba histolytica, transmitted in communities with poor sanitation are endemic in the Venda region of South Africa (2930). The presence of Vibrio, Salmonella, and Shigella species and the detection of total coliforms, faecal coliform, and enterococci counts far above the acceptable limits show how vulnerable the residents of Tshikuwi in South Africa were to episodes of di- arrhoea as a result of the poor microbial quality of water used in their homes.

The lack of treated potable water remains an important issue in many rural communities in the developing world, including South Africa. The frequent outbreaks of diarrhoea or gastroenteritis in rural communities in South Africa have all been attributed to the consumption of water of poor microbial quality. The study presented here highlights this ongoing problem. In this case, untreated groundwater was merely channelled through pipes into two storage tanks in Tshikuwi from which members of the community draw water through taps located at the base of the tanks. In addition, water was abstracted for use without prior treatment from the Khandanama river. We have shown that the water used by most households, i.e. water from Tank 1 and the Khandanama river in Tshikuwi at the time of the outbreak of diarrhoea in June-July 2006 was of poor microbial quality. Furthermore, the results of GIS analysis showed that the hot-spot of the outbreak of diarrhoea was linked to water from Tank 1 and the Khandamana river, both of which were the most contaminated as evidenced by microbiological analysis. Although Salmonella, Shigella, and Vibrio were not further characterized to species level, their presence in the Khandanama river is a cause of concern. S. dysenteriae type 1 and $V$. cholerae $\mathrm{O} 1$ biotype El Tor have been shown to cause epidemics in other parts of South Africa (19-20).

It is possible that adequate chlorination of the tank- and river-water, or boiling-water before domestic use and drinking would have been sufficient to avert the health crisis. The provision of clean water in terms of physico-chemical and microbial quality cannot be overemphasized as this impacts positively on poverty-alleviation efforts. This study highlights the need to monitor the quality of groundwater, in addition to sustained health-education programmes in communities without clean potable water to reduce health-risks through the use of contaminated water supplies.

\section{ACKNOWLEDGEMENTS}

The study was partially supported by the National Research Foundation, South Africa, through a grant awarded to Pascal Obong Bessong. The views expressed in this report are those of the authors. The authors thank the staff of the Tshikuwi Clinic for providing data on diarrhoea cases. The cordial participation of the households is appreciated. 


\section{REFERENCES}

1. World Health Organization. Global water supply and sanitation assessment 2000 report. Geneva: World Health Organization, 2000. 87 p.

2. Ashbolt NJ. Microbial contamination of drinking water and disease outcomes in developing regions. Toxicology 2004;198:229-38.

3. Obi CL, Green E, Bessong PO, de Villiers B, Igumbor EO, Potgieter N. Gene encoding virulence markers among Escherichia coli isolates from diarrhoiec stool samples and river sources in rural Venda communities of South Africa. Water SA 2004;30:37-42.

4. Obi CL, Potgieter N, Bessong PO, Matsaung G. Bacteriological assessment of quality of river water sources in rural Venda communities in South Africa. Water SA 2002;28:287-92.

5. South Africa. Department of Water Affairs and Forestry. South African water quality guidelines for domestic use. 2nd ed. V. 2. Recreational use. Pretoria: Department of Water Affairs and Forestry, Republic of South Africa, 1996:76-88.

6. Obi CL, Potgieter N, Bessong PO, Matsaung G. Scope of potential bacterial agents of diarrhoea and microbial assessment of quality of river water sources in rural Venda communities in South Africa. Water Sci Technol 2003;47:59-64.

7. Oswald WE, Lescano AG, Bern C, Calderon MM, Cabrera L, Gilman RH. Fecal contamination of drinking water within peri-urban households, Lima, Peru. Am J Trop Med Hyg 2007;77:699-704.

8. Do TT, Bui TT, Mølbak K, Phung DC, Dalsgaard A. Epidemiology and aetiology of diarrhoeal diseases in adults engaged in wastewater-fed agriculture and aquaculture in Hanoi, Vietnam. Trop Med Int Health 2007;12(Suppl 2):23-33.

9. Cronin AA, Shrestha D, Cornier N, Abdalla F, Ezard $\mathrm{N}$, Aramburu C. A review of water and sanitation provision in refugee camps in association with selected health and nutrition indicators-the need for integrated service provision. J Water Health 2008;6:1-13.

10. Njemanze PC, Anozie J, Ihenacho JO, Russell MJ, Uwaeziozi AB. Application of risk analysis and geographic information system technologies to the prevention of diarrheal diseases in Nigeria. Am J Trop Med Hyg 1999;61:356-60.

11. Lai PC, Wong CM, Hedley AJ, Lo SV, Leung PY, Kong $\mathrm{J}$ et al. Understanding the spatial clustering of severe acute respiratory syndrome (SARS) in Hong Kong. Environ Health Perspect 2004;112:1550-6.

12. Polack SR, Solomon AW, Alexander ND, Massae PA, Safari S, Shao JF et al. The household distribution of trachoma in a Tanzanian village: an application of GIS to the study of trachoma. Trans $R$ Soc Trop Med Hyg 2005;99:218-225.

13. Fang L, Yan L, Liang S, de Vlas SJ, Feng Dan, Han X et al. Spatial analysis of hemorrhagic fever with renal syndrome in China. BMC Infect Dis 2006;6:77. (doi:10.1186/1471-2334-6-77).

14. Sarkar R, Prabhakar AT, Manickam S, Selvapandian D, Raghava MV, Kang G et al. Epidemiological investigation of an outbreak of acute diarrhoeal disease using geographic information systems. Trans $R$ Soc Trop Med Hyg 2007;101:587-93.

15. Cifuentes E, Mazari-Hiriart M, Carneiro F, Bianchi F, Gonzalez D. The risk of enteric diseases in young children and environmental indicators in sentinel areas of Mexico City. Int J Environ Health Res 2002;12:53-62.

16. Schwartz BS, Harris JB, Khan AI, Larocque RC, Sack DA, Malek MA et al. Diarrheal epidemics in Dhaka, Bangladesh, during three consecutive floods: 1988, 1998, and 2004. Am J Trop Med Hyg 2006;74:1067-73.

17. Sur D, Dutta S, Sarkar BL, Manna B, Bhattacharya MK, Datta KK et al. Occurrence, significance \& molecular epidemiology of cholera outbreaks in West Bengal. Indian J Med Res 2007;125:772-6.

18. Morgan O, Milne L, Kumar S, Murray D, Man W, Georgiou M et al. Outbreak of Salmonella Enteritidis phage type 13a: case-control investigation in Hertsmere, United Kingdom. Euro Surveill 2007;12:E9-10.

19. Pegram GC, Rollins N, Espey Q. Estimating the cost of diarrhoea and epidemic dysentery in KwaZzuluNatal and South Africa. Water SA 1998;24:11-20.

20. Dalsgaard A, Forslund A, Sandvang D, Arntzen L, Keddy K. Vibrio cholerae O1 outbreak isolates in Mozambique and South Africa in 1998 are multiple-drug resistant, contain the SXT element and the aadA2 gene located on class 1 integrons. J Antimicrob Agents Chemother 2001;48:827-38.

21. Liesenfeld O, Weinke T, Hahn H. Three-year prevalence of enteropathogenic bacteria in an urban patient population in Germany. Infection 1993;21:101-5.

22. Quinn TC. Diversity of Campylobacter species and its impact on patients infected with human immunodeficiency virus. Clin Infect Dis 1997;24:1114-7.

23. Gassama A, Sow PS, Fall F, Camara P, Guèye-N'diaye A, Seng R et al. Ordinary and opportunistic enteropathogens associated with diarrhea in Senegalese adults in relation to human immunodeficiency virus serostatus. Int J Infect Dis 2001;5:192-8.

24. Coker AO, Isokpehi RD, Thomas BN, Amisu KO, Obi CL. Human campylobacteriosis in developing countries. Emerg Infect Dis 2002;8:237-434. 
25. Obi CL, Bessong PO. Diarrhoeagenic bacterial pathogens in HIV-positive patients with diarrhoea in rural communities of Limpopo province, South Africa. J Health Popul Nutr 2002;20:230-4.

26. Von Schirding I, Yeah D, Mathee A. Health aspects of sanitation with special reference to South Africa. J Comp Health 1993;4:73-9.

27. Nevondo TS, Cloete TE. Bacterial and chemical quality of water supply in the Dertig village settlement. Water SA 1999;25:215-20.

28. Tumwine JK, Thompson J, Katua-Katua M, Mujwajuzi $\mathrm{M}$, Johnstone N. Diarrhoea and effects of different water sources, sanitation and hygiene behaviour in East Africa. Trop Med Int Health 2002;7:750-6.

29. Samie A, Bessong PO, Obi CL, Sevilleja JE, Stroup S, Houpt E et al. Cryptosporidium species: preliminary descriptions of the prevalence and genotype distribution among school children and hospital patients in the Venda region, Limpopo province, South Africa. Exp Parasitol 2006;114:314-22.

30. Samie A, Obi LC, Bessong PO, Stroup S, Houpt E, Guerrant RL. Prevalence and species distribution of $E$. histolytica and E. dispar in the Venda region, Limpopo, South Africa. Am J Trop Med Hyg 2006;75:565-71. 